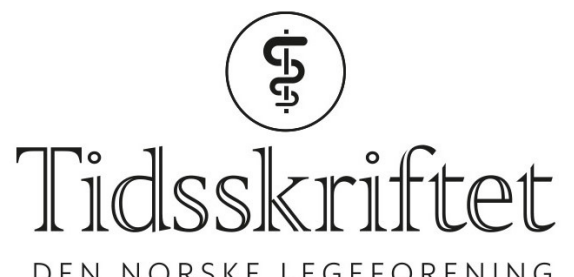

DEN NORSKE LEGEFORENING

\title{
Belastende livserfaringer blant pasienter med sykelig overvekt
}

ORIGINALARTIKKEL

\section{ELIN STRANDEN}

Fakultet for medisin og helsevitenskap

NTNU

Hun har bidratt til tilrettelegging, analyse og tolkning av data, litteraturs $ø$, utarbeiding og revisjon av manus og godkjenning av innsendte manusversjon.

Elin Stranden er medisinstudent.

Forfatteren har fylt ut ICMJE-skjemaet og oppgir ingen interessekonflikter.

\section{IDA FOYN GUNDERSEN}

Fakultet for medisin og helsevitenskap

NTNU

Hun har bidratt til tilrettelegging, analyse og tolkning av data, litteratursøk, utarbeiding og revisjon av manus og godkjenning av innsendte manusversjon.

Ida Foyn Gundersen er medisinstudent.

Forfatteren har fylt ut ICMJE-skjemaet og oppgir ingen interessekonflikter.

\section{LINN GETZ}

Allmennmedisinsk forskningsenhet Institutt for samfunnsmedisin og sykepleie NTNU

Hun har bidratt med idé, utforming, design, analyse og tolkning av data, litteraturs $ø \mathrm{k}$, utarbeiding og revisjon av manus og godkjenning av innsendte manusversjon.

Linn Getz er lege, professor i medisinske atferdsfag og leder av Allmennmedisinsk forskningsenhet ved NTNU.

Forfatteren har fylt ut ICMJE-skjemaet og oppgir ingen interessekonflikter.

\section{ANNA LUISE KIRKENGEN}

Allmennmedisinsk forskningsenhet Institutt for samfunnsmedisin og sykepleie NTNU

Hun har bidratt med idé, utforming, design, analyse og tolkning av data, litteratursøk, utarbeiding og revisjon av manus og godkjenning av innsendte manusversjon.

Anna Luise Kirkengen er professor emerita i allmennmedisin.

Forfatteren har fylt ut ICMJE-skjemaet og oppgir ingen interessekonflikter.

\section{KAI BRYNJAR HAGEN}

Regionalt senter for sykelig overvekt

Nordlandssykehuset, Bod $\emptyset$

Han har bidratt med idé, utforming, design, datainnsamling, utarbeiding og revisjon av manus og godkjenning av innsendte manusversjon.

Kai Brynjar Hagen er overlege.

Forfatteren har fylt ut ICMJE-skjemaet og oppgir ingen interessekonflikter. 
E-post: bente.mjolstad@ntnu.no

Allmennmedisinsk forskningsenhet

Institutt for samfunnsmedisin og sykepleie

NTNU

Hun har bidratt med idé, utforming, design, analyse og tolkning av data, litteratursøk, utarbeiding og revisjon av manus og godkjenning av innsendte manusversjon.

Bente Prytz Mjølstad er spesialist i allmennmedisin, fastlege og førsteamanuensis i allmennmedisin. Forfatteren har fylt ut ICMJE-skjemaet og oppgir ingen interessekonflikter.

Elin Stranden og Ida Foyn Gundersen har bidratt i like stor grad til denne artikkelen.

\section{BAKGRUNN}

Sammenhenger mellom sterkt belastende livserfaringer og sykelig overvekt er godt dokumentert internasjonalt, men kunnskapen er lite innarbeidet i norsk klinisk praksis. Vi har undersøkt hva et utvalg norske pasienter under utredning for sykelig overvekt rapporterte om tidligere livsbelastninger ved et senter der temaet livserfaringer inngikk i anamneseopptaket.

\section{MATERIALE OG METODE}

Invitasjon til studien ble sendt til de 200 sist utredede pasientene ved Regionalt senter for sykelig overvekt i Bodø sommeren 2018. Opplysninger om belastende livserfaringer ble innhentet i kliniske dialoger. Data ble hentet fra deltakernes epikriser, og epikrisetekstene ble analysert med en kvalitativ tilnærming. Belastende livserfaringer ble inndelt i tolv kategorier.

\section{RESULTATER}

Studien rekrutterte 70 deltakere ( 57 kvinner) med sykelig overvekt. Av disse fortalte 64 (91\%) om minst én vesentlig og belastende livserfaring, og 39 (56\%) om tre eller flere ulike typer. Hyppigst var alvorlige relasjonsbrudd, manglende omsorg fra foreldre og andre vonde barndomserfaringer.

\section{FORTOLKNING}

Blant et utvalg av norske pasienter under utredning for sykelig overvekt rapporterte mange om vonde livshistorier. Mangel på eksistensiell trygghet i barndom, ofte knyttet til komplekse traumer, var fremtredende. I lys av internasjonal forskning om sammenhenger mellom traumer og fedme, indikerer våre resultater at pasientens livshistorie bør inngå i utredning av sykelig overvekt.

Fedme er en av samtidens store helseutfordringer. Utviklingen er knyttet til en kompleks dynamikk mellom matvaner, fysisk aktivitet, fysiologi, genetikk og epigenetikk i en globalisert verden der tilgangen til energitett mat for mange mennesker er bortimot ubegrenset $(1,2)$. Solid internasjonal dokumentasjon har dessuten vist at belastende livshendelser kan bidra signifikant til utvikling av fedme, gjennom både emosjonelle og fysiologiske prosesser (3-9). I 1998 viste den amerikanske ACE-studien (Adverse Childhood Experiences) en dose-respons-sammenheng mellom traumatiske barndomserfaringer og sykelig fedme i voksenlivet (5). Flere metaanalyser har de siste årene bekreftet og utdypet sammenhengene mellom traumatiske erfaringer i barndommen og fedme i voksen alder $(8$, 9). I materialet fra Helseundersøkelsen i Nord-Trøndelag (HUNT, 2006-o8) fant vi blant voksne deltakere en liknende dose-respons-sammenheng mellom grad av selvrapportert, vanskelig barndom og en rekke former for sykelighet senere i livet, inkludert fedme. I HUNT-studien rapporterte 4,1 \% av de voksne deltakerne at de hadde hatt en «vanskelig» 
eller «svært vanskelig» barndom (6).

Pasienter med sykelig overvekt (BMI $\geq 40 \mathrm{~kg} / \mathrm{m}^{2}$ eller BMI $\geq 35 \mathrm{~kg} / \mathrm{m}^{2}$ med vektrelatert tilleggssykdom) kan henvises fra fastlegen til spesialisthelsetjenesten, hvor de tilbys veiledning om livsstil og eventuelt også bariatrisk kirurgi (10). Flere metaanalyser har de siste årene bekreftet og utdypet sammenhengene mellom traumatiske erfaringer i barndommen og fedme i voksen alder $(8,9)$. Likevel er denne kunnskapen lite innarbeidet $\mathrm{i}$ norsk klinisk praksis, og kun nevnt med vage anbefalinger i retningslinjer for helsepersonell (10).

Ved Regionalt senter for sykelig overvekt i Bodø har samtaler om belastende livserfaringer i noen år inngått i utredningen. Dette har vært begrunnet i kunnskap om, og klinisk erfaring av, at en slik tilnærming bidrar til økt innsikt i fedmens komplekse årsaker (11). Mange av pasientene har fortalt om store livsbelastninger, og flere har blitt henvist til traumeterapi. Dette er bakgrunnen for vårt prosjekt, som også inkluderer en hovedoppgave på medisinstudiet ved NTNU (12).

Målet med prosjektet var å dokumentere og analysere hva pasienter som utredes ved et regionalt senter for sykelig overvekt i Norge, selv valgte å fortelle da en erfaren lege signaliserte åpenhet for å snakke om vanskelige livserfaringer.

\section{Materiale og metode}

Data stammer fra epikrisene til pasienter nylig utredet for sykelig overvekt ved Regionalt senter for sykelig overvekt i Bodø. Utredningen er beskrevet i ramme 1. Invitasjon til deltakelse i studien ble sommeren 2018 sendt til de 200 sist undersøkte pasientene ved senteret. Behandlende lege og en forskningssykepleier hentet avidentifiserte data fra epikrisene til pasientene som samtykket til deltakelse. Studien var godkjent av regional komite for medisinsk og helsefaglig forskningsetikk (REK nord 2018/1002) og Norsk senter for forskningsdata (NSD).

\section{Ramme 1 Utredning ved Regionalt senter for sykelig overvekt i Bodø.}

Tredjelinjetjeneste

Pasientene henvises vanligvis fra lokalsykehuset, vurdert etter følgende kriterier:

- $B M I \geq 40 \mathrm{~kg} / \mathrm{m}^{2}$ eller $\geq 35 \mathrm{~kg} / \mathrm{m}^{2}$ med følgesykdom

- Pasienten ønsker selv konservativ eller operativ behandling

- Behandlingsforsøk på seks måneder lokalt

Utredningsopphold

Utredningen varer vanligvis i én-tre dager

Legeundersøkelse utføres av den samme overlegen, varer i én time og består av:

- Generell anamnese inkludert spørsmål om belastende livserfaringer

- Klinisk undersøkelse, inkludert tannhelsestatus

- Relevante laboratorieprøver

Belastende livserfaringer

Som en del av anamnesen kommer legen inn på følgende forhold (åpne spørsmål):

- Opplevd trygghet i hjemmet som barn og ung

- Sosial deltakelse sammen med jevnaldrende

- Fysisk aktivitet i barne- og ungdomsår 
- Skolefaglig mestring

- Livshendelser i perioden forut for en eventuell dramatisk vektøkning

Notatene som beskriver livserfaringer, blir vanligvis formulert i løpet av konsultasjonen i samarbeid mellom lege og pasient, og varierer i omfang fra noen få linjer til en halv side per pasient.

Det blir ikke benyttet standardisert intervjuguide eller spørreskjema for å kartlegge pasientens livserfaringer, og det blir ikke stilt spesifikke traumespørsmål.

70 pasienter ( 57 kvinner) returnerte signert samtykkeskjema og ble inkludert i studien. Bakgrunnsinformasjon om de inkluderte pasientene vises i tabell 1. Vi vurderte utvalget som relevant, variert og velegnet for formålet med studien (13).

\section{Tabell 1}

Karakteristika ved de 70 deltakende pasientene utredet for sykelig overvekt ved Regionalt senter for sykelig overvekt i Bodø. Antall dersom annet ikke er angitt.

\begin{tabular}{|c|c|}
\hline Variabel & Verd \\
\hline \multicolumn{2}{|l|}{ Kjønn } \\
\hline Kvinner & 57 \\
\hline Menn & 13 \\
\hline \multicolumn{2}{|l|}{ Alderskategorier } \\
\hline $20-39$ år & 15 \\
\hline $40-59$ år & 45 \\
\hline $60-79$ år & 10 \\
\hline \multicolumn{2}{|l|}{ Sivilstatus } \\
\hline Gift/samboer & 47 \\
\hline \multicolumn{2}{|l|}{ Utdanning } \\
\hline Fullført grunnskole & 23 \\
\hline Fullført videregående skole & 33 \\
\hline Fullført høyere utdanning & 13 \\
\hline Ukjent & 1 \\
\hline \multicolumn{2}{|l|}{ Arbeidsliv } \\
\hline Yrkesaktiv & 33 \\
\hline Uføretrygdet, gradert eller hel & 20 \\
\hline Annet & 17 \\
\hline BMI $\left(\mathrm{kg} / \mathrm{m}^{2}\right)$, gjennomsnitt (variasjonsbredde) & $43(30-63)$ \\
\hline Maksimal vekt $(\mathrm{kg})$, gjennomsnitt (variasjonsbredde) & $133(103-201)$ \\
\hline
\end{tabular}

\section{ANALYSER}

Metoden er inspirert av fortolkende, fenomenologisk analyse $(14,15)$. Alle medforfatterne gjennomgikk materialet hver for seg og identifiserte preliminære kategorier av belastende livserfaringer. Materialet ble så gjennomgått i fellesskap. Divergerende tolkninger ble diskutert og endelige kategorier formulert. Kategorier som sto i direkte samsvar med forskning på feltet, ble først identifisert (5). Dernest definerte vi noen nye kategorier i lys av eksisterende litteratur. Behandlende lege deltok i sluttfasen av analysen og validerte den endelige kategoriseringen. De belastende livshendelsene er gjengitt i stikkordsform og uten henvisning til alder og kjønn for å sikre anonymisering.

\section{Resultater}

Analysen resulterte i tolv kategorier av belastende livserfaringer (ramme 2). 


\section{Ramme 2 Oversikt over de tolv kategoriene av belastende livserfaringer som ble identifisert i studien, med prosentandel av deltakere som rapporterte livserfaringer innen hver kategori.}
1. Opplevelse av vesentlig utrygghet (39\%)
2. Følelse av manglende omsorg fra foreldre (41\%)
3. Vitne til vold ( $9 \%)$
4. Utsatt for fysisk vold ( $26 \%)$
5. Utsatt for psykisk vold (34\%)
6. Utsatt for seksuelt misbruk/overgrep (29\%)
7. Utsatt for mobbing (29\%)
8. Alvorlige relasjonsbrudd (66\%)
9. Rus i nær relasjon (24\%)
10. Belastende omsorgsansvar (27\%)
11. Traumatisk møte med tannlege/helsevesen (24\%)
12. Annet traume av personlig betydning (21\%)

Figur 1 viser fordeling av ulike typer av belastende livserfaringer (antall kategorier) blant de 70 deltakerne. Kategoriene er beskrevet i ramme 2. Eksempler fra de tolv erfaringskategoriene er gjengitt i tabell 2.

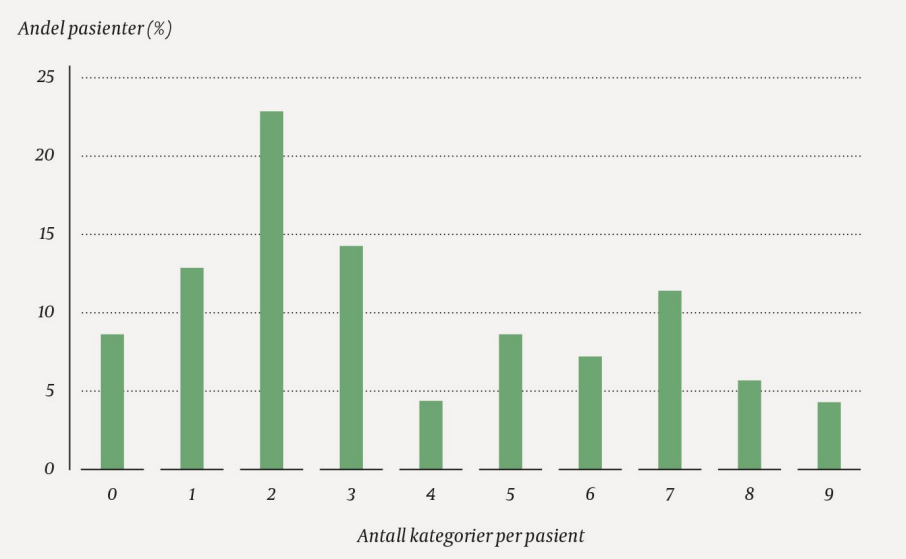

Figur 1 Fordeling av antall ulike kategorier av belastende livserfaringer blant de 70 pasientene. Kategoriene er beskrevet i ramme 2 .

\section{Tabell 2}

Eksempler på enkeltstående dokumenterte erfaringer innen hver av de tolv kategoriene, representert ved ulike pasienter i studien. For å sikre anonymisering er disse angitt i stikkordsform og uten henvisning til alder eller kjønn. 


\begin{tabular}{|c|c|c|}
\hline Kategori & Innhold i kategorien & Eksempel (stikkord) \\
\hline $\begin{array}{l}\text { 1. Opplevelse av } \\
\text { vesentlig utrygghet }\end{array}$ & $\begin{array}{l}\text { Eksplisitt beskrivelse av } \\
\text { grunnleggende utrygghetsfølelse } \\
\text { tidlig i livet med ulike } \\
\text { bakenforliggende årsaker. }\end{array}$ & $\begin{array}{l}\text { Utrygge hjemmeforhold i } \\
\text { oppveksten, til dels } \\
\text { traumatiserende. } \\
\text { Ensomhetsfølelse. }\end{array}$ \\
\hline $\begin{array}{l}\text { 2. Følelse av manglende } \\
\text { omsorg }\end{array}$ & $\begin{array}{l}\text { Eksplisitt beskrivelse av opplevd } \\
\text { manglende omsorg fra én eller } \\
\text { begge foreldre under oppveksten. }\end{array}$ & $\begin{array}{l}\text { Som barn fått beskjed fra } \\
\text { mor om å ha vært } \\
\text { uønsket og at en ikke } \\
\text { skulle vært født. }\end{array}$ \\
\hline 3. Vitne til vold & $\begin{array}{l}\text { Vitne til vold mellom foreldrene } \\
\text { som barn. }\end{array}$ & $\begin{array}{l}\text { Som barn redd for å få } \\
\text { juling av far. Så at far var } \\
\text { voldelig mot mor. }\end{array}$ \\
\hline 4. Utsatt for fysisk vold & $\begin{array}{l}\text { Fysisk vold i barndom og voksen } \\
\text { alder. I hovedsak jenter som blir } \\
\text { utsatt for vold fra sin far, eller } \\
\text { kvinner som blir utsatt for vold fra } \\
\text { sin samlivspartner. }\end{array}$ & $\begin{array}{l}\text { Utsatt for grov vold av } \\
\text { far i oppveksten. } \\
\text { Barnevernet involvert. }\end{array}$ \\
\hline $\begin{array}{l}\text { 5. Utsatt for psykisk } \\
\text { vold }\end{array}$ & $\begin{array}{l}\text { Trusler, trakassering og } \\
\text { kontrollering fra nære relasjoner. }\end{array}$ & $\begin{array}{l}\text { Ble kontrollert og styrt, } \\
\text { senere drapstruet av } \\
\text { partner. }\end{array}$ \\
\hline $\begin{array}{l}\text { 6. Utsatt for seksuelt } \\
\text { misbruk/overgrep }\end{array}$ & $\begin{array}{l}\text { Voldtekt i barndom eller voksen } \\
\text { alder, og/eller incesterfaringer. }\end{array}$ & $\begin{array}{l}\text { I mange år utsatt for } \\
\text { grove seksuelle overgrep } \\
\text { fra far og flere voksne. }\end{array}$ \\
\hline 7. Utsatt for mobbing & $\begin{array}{l}\text { Mobbing fra medelever på skolen, } \\
\text { hos mange inkludert fysisk vold. } \\
\text { Noen har også opplevd mobbing } \\
\text { fra foreldre eller lærere. }\end{array}$ & $\begin{array}{l}\text { Grov mobbing store } \\
\text { deler av skolegangen, } \\
\text { med fysisk vold nesten } \\
\text { hver dag. Ingen tok } \\
\text { affære. }\end{array}$ \\
\hline $\begin{array}{l}\text { 8. Alvorlige } \\
\text { relasjonsbrudd }\end{array}$ & $\begin{array}{l}\text { Tap eller atskillelse fra viktige, } \\
\text { nære relasjoner. Om lag halvparten } \\
\text { av historiene innebærer dramatiske } \\
\text { eller nære dødsfall. Over } \\
\text { halvparten innebærer belastende } \\
\text { samlivsbrudd - enten hos } \\
\text { pasientenes foreldre eller hos } \\
\text { pasienten selv i voksen alder. }\end{array}$ & $\begin{array}{l}\text { Mistet nærstående i } \\
\text { dramatisk ulykke som } \\
\text { barn. }\end{array}$ \\
\hline 9. Rus i nær relasjon & $\begin{array}{l}\text { Vesentlig påvirket av å leve med en } \\
\text { ruset omsorgsperson/partner. }\end{array}$ & $\begin{array}{l}\text { I perioder alene med } \\
\text { alkoholisert forelder med } \\
\text { store humørsvingninger. }\end{array}$ \\
\hline $\begin{array}{l}\text { 10. Belastende } \\
\text { omsorgsansvar }\end{array}$ & $\begin{array}{l}\text { Omsorg for barn med særskilte } \\
\text { behov, aleneomsorg for flere barn i } \\
\text { kombinasjon med trang økonomi } \\
\text { og/eller vanskelige relasjoner, } \\
\text { omsorgsansvar for ektefeller, tidlig } \\
\text { omsorgsansvar for foreldre/søsken } \\
\text { under oppveksten. }\end{array}$ & $\begin{array}{l}\text { Eneforsørger for familie. } \\
\varnothing \text { konomiske problemer. } \\
\text { Svært lite søvn over } \\
\text { mange år. }\end{array}$ \\
\hline $\begin{array}{l}\text { 11. Traumatisk møte } \\
\text { med } \\
\text { tannlege/helsevesen }\end{array}$ & $\begin{array}{l}\text { Smertefulle prosedyrer, fysisk } \\
\text { tvang under tannlege-/legebesøk, } \\
\text { tannlege som fremsto beruset. }\end{array}$ & $\begin{array}{l}\text { Tannlegeskrekk etter } \\
\text { tanntrekking uten } \\
\text { bedøvelse som barn. }\end{array}$ \\
\hline $\begin{array}{l}\text { 12. Annet traume av } \\
\text { personlig betydning }\end{array}$ & $\begin{array}{l}\text { Historier som ikke passer i de } \\
\text { andre kategoriene, men som } \\
\text { pasientene har beskrevet som } \\
\text { sterkt belastende. }\end{array}$ & $\begin{array}{l}\text { Beskjed om alvorlig } \\
\text { sykdom med mulig kort } \\
\text { leveutsikt. }\end{array}$ \\
\hline
\end{tabular}

Av de 70 deltakerne fortalte 64 (91\%) om minst én vesentlig, belastende livserfaring, og 39 ( $56 \%$ ) om tre eller flere typer av ulik art. Hyppigst var alvorlige relasjonsbrudd, manglende omsorg fra foreldre og vesentlig utrygghet i barndommen (ramme 2). Alvorlige relasjonsbrudd dreide seg om tap av, eller atskillelse fra, viktige og nære personer. Her inngikk dramatiske eller nære dødsfall og belastende samlivsbrudd, hos enten pasientens foreldre eller pasienten selv. Ikke sjelden var det samtidig psykisk sykdom, rus eller vold med i bildet. 36 pasienter ( $51 \%$ ) fortalte at de hadde vært utsatt for én eller flere typer av vold eller seksuelle overgrep (kategori 3-6), og 17 (24\%) fortalte om rus i nær relasjon (kategori 9). I forbindelse med undersøkelse av tannstatus fortalte 33 (47\%) om tannlegeskrekk, hvorav 17 (24\%) fortalte om brutale erfaringer hos tannlege under oppveksten (kategori 11). 


\section{Diskusjon}

Fra et utvalg på 70 pasienter fra et norsk regionalt senter for sykelig overvekt tilordnet vi disse pasientenes ulike belastende livserfaringer og traumer til tolv kategorier. Over halvparten av pasientene hadde erfaringer som samsvarte med tre eller flere av kategoriene. Hyppigst forekom alvorlige relasjonsbrudd, vesentlig utrygghet i barndom og følelse av manglende omsorg fra foreldre. Dernest fulgte en serie mer spesifikt definerte erfaringer, som for eksempel seksuelt misbruk eller det å ha vært vitne til vold. Som figur 1 og tabell 2 illustrerer, omfatter datamaterialet flere komplekse livshistorier som i stikkordsform beskriver en serie belastende og sammenvevede erfaringer. Erfaringer av relasjonsbrudd, vold og utrygghet tidlig i livet dukket ikke sjelden opp i nye konstellasjoner i pasientenes voksne liv.

Studiens design ble valgt fordi vi ønsket å utforske et tema som ifølge internasjonal forskning er viktig, men som vi mangler kunnskap om i norsk sammenheng (16). Deltakerne var heterogene med henblikk på alder, sivilstatus, utdanning og arbeidsdeltakelse, noe som taler for at funnene kan ha overføringsverdi til liknende pasientgrupper. Kvinneandelen ( $81 \%$ ) var litt høyere enn andelen ved angjeldende Regionalt senter for sykelig overvekt i Bodø (70\%). Ellers er det vanskelig å vite om deltakerne skiller seg vesentlig fra dem som ikke svarte på invitasjonen.

Studiens formål var ikke å fremskaffe allmenngyldige prevalensdata eller å si noe direkte om årsakssammenhenger mellom traumer og fedme. Studien gir derimot innsikt i hva et utvalg på 70 pasienter med sykelig overvekt valgte å fortelle en erfaren lege som ga rom for dialog om belastende livserfaringer. Resultatene bør sees i lys av at underrapportering av traumer og overgrep anses å være vanlig, både i klinisk praksis og forskning $(16,17)$. Deltakerne har selv oppfattet erfaringene som relevante i den gitte medisinske situasjonen, og de bidro aktivt til hvordan disse ble dokumentert.

Vi var under analysen bevisste vår forforståelse og unngikk etter beste evne forutinntatte tolkninger. Vi erkjente at viktige nyanser i de individuelle historiene lett kunne gå tapt eller feiltolkes. Mange beskrivelser pekte mot sammensatte erfaringer som kunne tilordnes flere kategorier. Så langt som mulig ble erfaringene kategorisert i direkte samsvar med formuleringene i epikrisen. For eksempel ble informasjon om tap av en forelder (kategori 8) ikke også kategorisert som følelse av utrygghet i barndom (kategori 1), med mindre det var eksplisitt beskrevet.

Analysen tok sikte på å identifisere ulike kategorier av belastende livserfaringer med klinisk relevans. En slik analyseprosess kan drives av eksisterende teori og evidens, og bidra til utvikling av ny teori (14). Analysen var influert av forfattergruppens generelle kjennskap til og forskning på sammenhenger mellom livserfaringer og sykdom (6, 18-19).

Mange av kategoriene (nummer 2, 4-9 og 12 i ramme 2) kunne umiddelbart forankres i tre sentrale, internasjonale studier $(5,20,21)$. Materialet ga dernest grunnlag for å definere noen flere kategorier (nummer 1,3,10 og 11) som også kan relateres til relevant dokumentasjon (se eksempler nedenfor). Den internasjonale litteraturen på feltet omfatter både klinisk forskning, basalforskning og epidemiologiske studier $(12,16)$. Flere publikasjoner dokumenterer generelle sammenhenger mellom stressende erfaringer på den ene siden og følelsesstyrte spisemønstre og fedmeutvikling på den andre (4). Innsikten i fysiologien som knytter stress til forstyrret metabolisme, apetittregulering og fedme, er raskt voksende (22). Videre finnes epidemiologiske studier av sammenhenger mellom fedme og én eller noen få traumekategorier (omtales i 12).

En fellesnevner for flere av erfaringskategoriene synes å være mental «alarmberedskap» i lange perioder. Kategoriene $1 \operatorname{og} 2$ peker mot grunnleggende mangel på eksistensiell trygghet tidlig i livet. De biologiske «kostnadene» av slik alarmberedskap står sentralt i moderne stressforskning, inkludert modellen for allostatisk overbelastning. Den beskriver sammenhenger mellom langvarig stress, fysiologisk dysregulering og sykdomsutvikling, inkludert fedme $(23,24)$. I Hemmingssons fedmemodell står også følelse av usikkerhet og 
utrygghet sentralt (4). ACE-studien viste en dose-respons-sammenheng mellom traumatiske livserfaringer og sykelig fedme (5). Senere studier har bekreftet disse sammenhengene for seksuelt misbruk, andre former for vold, emosjonell mishandling eller vanskjøtsel og rusmisbruk i hjemmet $(3,7,9)$. Relasjonsbrudd i form av tidlig tap av en forelder $\emptyset$ ker risikoen for fedmeutvikling, uavhengig av andre belastende livshendelser (25, 26). Mobbing og fedme er gjensidig assosiert $(27,28)$. Langvarig, belastende omsorgsansvar er assosiert med belastning av fysiologien, og en sammenheng med fedme er derfor plausibel (29).

Vårt materiale inneholder flere eksempler på dårlig tannhelse og tannlegeskrekk. Stress i barndommen er assosiert med kronisk systemisk inflammasjon, som igjen kan interagere med uheldig kosthold og dårlig tannstell (30). Volds- og overgrepserfaringer disponerer for tannlegeskrekk (31). Belastende barndomserfaringer kan altså via flere mekanismer øke risikoen for dårlig tann- og munnhelse (30, 31).

Et viktig funn i studien er at mange deltakere rapporterte flere typer belastende livserfaringer og dermed illustrerer relevansen av termen «komplekse traumer», ikke minst med tanke på utsatte barns oppvekstsvilkår (32). Et annet fremtredende funn var at deltakere som hadde opplevd vold eller krenkelser i barndommen, var utsatt for nye hendelser i voksenlivet - såkalt re-viktimisering (33).

Vi håper studien kan motivere klinikere til å opptre åpent og lyttende i møte med sterkt overvektige pasienter. Å tematisere vonde livserfaringer og traumer i relevante kliniske sammenhenger medfører ikke re-traumatisering $(16,17)$. En traumesensitiv anamnese som ikke umiddelbart legger føringer for bestemte typer informasjon, kan åpne for betydningsfulle tema uten å virke invaderende (34) og bidra til dypere og mer adekvat innsikt i kompleksiteten bak overvektsproblematikk. Slik innsikt kan styrke pasientens selvforståelse og selvfølelse og redusere stigma og skam knyttet til fedme. Dette er i seg selv helsefremmende $(11,35,36)$. Nåværende standardiserte pasientforløp legger i liten grad til rette for helhetlig og traumesensitiv utredning og behandling av sykelig overvekt og de sammensatte helseproblemene knyttet til en slik diagnose. Det er en stor utfordring å komme frem til faglig enighet om nye, egnede måter å arbeide på. En integrert tilnærming forutsetter ikke bare velfungerende, logistisk samarbeid på tvers av dagens skillelinjer mellom somatisk og psykisk helsetjeneste. Den forutsetter også en oppdatert og ikkedualistisk forståelse av kropp og sykdom (19).

\section{HOVEDFUNN}

Vi fant mange sterke beretninger om belastende livserfaringer blant 7o pasienter utredet ved et norsk regionalt senter for sykelig overvekt.

En fellesnevner for flere av erfaringskategoriene var konstant «alarmberedskap» i lange perioder av personens liv, ofte med start i barndommen.

\section{LITTERATUR:}

1. Brandkvist M, Bjørngaard JH, Ødegård RA et al. Quantifying the impact of genes on body mass index during the obesity epidemic: longitudinal findings from the HUNT Study. BMJ 2019; 366: 14067.

[PubMed][CrossRef]

2. WHO. Obesity and overweight.

https://www.who.int/news-room/fact-sheets/detail/obesity-and-overweight/ Lest 11.5.2020.

3. Følling IS, Solbjør M, Helvik AS. Previous experiences and emotional baggage as barriers to lifestyle change - a qualitative study of Norwegian Healthy Life Centre participants. BMC Fam Pract 2015; 16: 73. [PubMed][CrossRef]

4. Hemmingsson E. A new model of the role of psychological and emotional distress in promoting 
obesity: conceptual review with implications for treatment and prevention. Obes Rev 2014; 15: 769-79. [PubMed][CrossRef]

5. Felitti VJ, Anda RF, Nordenberg D et al. Relationship of childhood abuse and household dysfunction to many of the leading causes of death in adults. The Adverse Childhood Experiences (ACE) Study. Am J Prev Med 1998; 14: 245-58. [PubMed][CrossRef]

6. Tomasdottir MO, Sigurdsson JA, Petursson $\mathrm{H}$ et al. Self-reported childhood difficulties, adult multimorbidity and allostatic load. A cross-sectional analysis of the Norwegian HUNT Study. PLoS One 2015; 10: e0130591. [PubMed][CrossRef]

7. Stensland $S \emptyset$, Thoresen S, Wentzel-Larsen T et al. Interpersonal violence and overweight in adolescents: the HUNT Study. Scand J Public Health 2015; 43: 18-26. [PubMed][CrossRef]

8. Danese A, Tan M. Childhood maltreatment and obesity: systematic review and meta-analysis. Mol Psychiatry 2014; 19: 544-54. [PubMed][CrossRef]

9. Hemmingsson E, Johansson K, Reynisdottir S. Effects of childhood abuse on adult obesity: a systematic review and meta-analysis. Obes Rev 2014; 15: 882-93. [PubMed][CrossRef]

10. Nasjonale faglige retningslinjer: Forebygging, utredning og behandling av overvekt og fedme hos voksne. Rapport IS-1735. Oslo: Helsedirektoratet, 2010.

https://www.helsedirektoratet.no/retningslinjer/overvekt-og-fedme-hos-voksne/Overvekt\%20og\%2ofe dme\%2ohos\%2ovoksne\%20-\%2oNasjonal\%2ofaglig\%2oretningslinje\%2ofor\%2oforebygging,\%2outrednin g\%20og\%2obehandling.pdf/_/attachment/inline/24ec824b-646d-4248-951f-

db6b867ce6cb:4e074ob933ffd5bco3c8fofdcaboob4135fe4ae9/Overvekt\%2oog\%2ofedme\%2ohos\%2ovoks ne\%20-\%2oNasjonal\%2ofaglig\%2oretningslinje\%2ofor\%2oforebygging,\%2outredning\%2oog\%2obehandli ng.pdf Lest 11.5.2020.

11. Hagen KB. Lessons on causality from clinical encounters with severely obese patients. I: Anjum RL, Copeland S, Rocca E, red. Rethinking Causality, Complexity and Evidence for the Unique Patient. A CauseHealth Resource for Health Care Professionals and the Clinical Encounter. Dordrecht: Springer Nature, 2020.

12. Gundersen IF, Stranden E. Livshistorier og fedmeutvikling. Hovedoppgave, medisinstudiet NTNU, Trondheim 2019. https://hdl.handle.net/11250/2679715 Data lest 10.11.2020.

13. Malterud K, Siersma VD, Guassora AD. Sample size in qualitative interview studies: Guided by Information Power. Qual Health Res 2016; 26: 1753-6o. [PubMed][CrossRef]

14. Kvale S. The qualitative research interview: A phenomenological and and a hermeneutical mode of understanding. J Phenomenological Psychol 1983; 14: 171-96. [CrossRef]

15. Smith JA, Jarman M, Osborn M. Doing interpretative phenomenological analysis. I: Murray M, Chamberlain K, red. Qualitative Health Psychology: Theories and Methods. Kap. 14. London: SAGE Publications Ltd, 1999.

16. Mason SM, Bryn Austin S, Bakalar JL et al. Child maltreatment's heavy toll: The need for traumainformed obesity prevention. Am J Prev Med 2016; 50: 646-9. [PubMed][CrossRef]

17. Becker-Blease KA, Freyd JJ. Research participants telling the truth about their lives: the ethics of asking and not asking about abuse. Am Psychol 2006; 61: 218-26. [PubMed][CrossRef]

18. Kirkengen AL, Næss AB. Hvordan krenkede barn blir syke voksne. 3. utg. Oslo: Universitetsforlaget, 2015 .

19. Getz L, Kirkengen AL, Ulvestad E. Kroppsliggjøring av erfaring og mening- belastende erfaringers innvirkning på menneskets biologi. I: Mæland JG, red. Sykdommers sosiale røtter. Oslo: Gyldendal Akademisk, 2020: 205-30.

20. Mäkinen T, Laaksonen M, Lahelma E et al. Associations of childhood circumstances with physical and mental functioning in adulthood. Soc Sci Med 2006; 62: 1831-9. [PubMed][CrossRef]

21. Surtees PG, Wainwright NWJ. The shackles of misfortune: social adversity assessment and representation in a chronic-disease epidemiological setting. Soc Sci Med 2007; 64: 95-111. [PubMed][CrossRef]

22. Michels N. Biological underpinnings from psychosocial stress towards appetite and obesity during youth: research implications towards metagenomics, epigenomics and metabolomics. Nutr Res Rev 
2019; 32: 282-93. [PubMed][CrossRef]

23. McEwen BS. Brain on stress: how the social environment gets under the skin. Proc Natl Acad Sci U S A 2012; 109 (Suppl 2): 17180-5. [PubMed][CrossRef]

24. Cedillo YE, Murillo AL, Fernández JR. The association between allostatic load and anthropometric measurements among a multiethnic cohort of children. Pediatr Obes 2019; 14: e12501.

[PubMed][CrossRef]

25. Lynch BA, Agunwamba A, Wilson PM et al. Adverse family experiences and obesity in children and adolescents in the United States. Prev Med 2016; 90: 148-54. [PubMed][CrossRef]

26. Alciati A, Caldirola D, Grassi M et al. Mediation effect of recent loss events on weight gain in obese people who experienced childhood parental death or separation. J Health Psychol 2017; 22: 101-10.

[PubMed][CrossRef]

27. Baldwin JR, Arseneault L, Odgers C et al. Childhood bullying victimization and overweight in young adulthood: A cohort study. Psychosom Med 2016; 78: 1094-103. [PubMed][CrossRef]

28. Puhl RM, Latner JD, O’Brien K et al. Cross-national perspectives about weight-based bullying in youth: nature, extent and remedies. Pediatr Obes 2016; 11: 241-50. [PubMed][CrossRef]

29. Epel ES, Blackburn EH, Lin J et al. Accelerated telomere shortening in response to life stress. Proc Natl Acad Sci U S A 2004; 101: 17312-5. [PubMed][CrossRef]

30. Boyce WT, Den Besten PK, Stamperdahl J et al. Social inequalities in childhood dental caries: the convergent roles of stress, bacteria and disadvantage. Soc Sci Med 2010; 71: 1644-52.

[PubMed][CrossRef]

31. Willumsen T. The impact of childhood sexual abuse on dental fear. Community Dent Oral Epidemiol 2004; 32: 73-9. [PubMed][CrossRef]

32. Braarud HC, Nordanger DØ. Komplekse traumatisering hos barn: en utviklingspsykologisk forståelse Tidsskr Nor psykologforen 2011; 48: 968-72.

33. Frugaard Stroem I, Aakvaag HF, Wentzel-Larsen T. Characteristics of different types of childhood violence and the risk of revictimization. Violence Against Women 2019; 25: 1696-716.

[PubMed][CrossRef]

34. Raja S, Hasnain M, Hoersch M et al. Trauma informed care in medicine: current knowledge and future research directions. Fam Community Health 2015; 38: 216-26. [PubMed][CrossRef]

35. Daly M, Sutin AR, Robinson E. Perceived weight discrimination mediates the prospective association between obesity and physiological dysregulation: Evidence from a population-based cohort. Psychol Sci 2019;30: 1030-9. [PubMed][CrossRef]

36. Vadiveloo M, Mattei J. Perceived weight discrimination and 10-year risk of allostatic load among US adults. Ann Behav Med 2017; 51: 94-104. [PubMed][CrossRef]

Publisert: 9. november 2020. Tidsskr Nor Legeforen. DOI: 10.4045/tidsskr.20.0103

Mottatt 4.2.2020, første revisjon innsendt 25.5.2020, godkjent 23.9.2020.

(C) Tidsskrift for Den norske legeforening 2020. Lastet ned fra tidsskriftet.no 